\title{
PHYTOPLASMA DETECTION IN ROSE SHOOTS PROPAGATED IN VITRO
}

\author{
Maria KAmińsKa, MaŁgorZata PodwyszyńsKa, Hanna Śliwa \\ Research Institute of Pomology and Floriculture \\ Pomologiczna 18, 96-100 Skierniewice, Poland \\ e-mail:mkaminsk@insad.pl
}

(Received: October 22, 2004. Accepted: January 20, 2005)

\begin{abstract}
The results of PCR examination indicated that during two years of tissue culture at standard conditions, on the medium with BAP $1 \mathrm{mg} \mathrm{l}^{-1}$ and continuous temperature of $20^{\circ} \mathrm{C}$, phytoplasma could be detected in diseased plants of rose cv Sacha and Jazz. In the second year of micropropagation phytoplasma detection rate in tissues of infected roses increased and was relatively higher than in the first one. To test whether phytoplasmas are sensitive to temperature and light intensity, phytoplasma-affected micropropagated rose plants were grown on medium with BAP 1.0 or $0.5 \mathrm{mg} \mathrm{l}^{-1}$ and at the temperature of $4,15,20$ or $25^{\circ} \mathrm{C}$ in darkness or in the light. PCR analysis indicated that phytoplasma detection was not effected by these conditions during 4 weeks of culturing. However, phytoplasma was not detectable in rose plants after 8 weeks culturing on the same medium without transplanting. Micropropagated rose shoots maintained on medium with Gentamycin or Baytril at the concentration of 25.0 or 50.0 $\mathrm{mg}^{-1}$ had reduced growth and were chlorotic. However, no direct effect of applied antibiotics on phytoplasma detection was evidenced.
\end{abstract}

KEY WORDS: rose, micropropagation, phytoplasma, antibiotics.

\section{INTRODUCTION}

Virus-like diseases of rose plants, called rose degeneration (Thomas 1979), of uncertain aetiology have been distributed in several countries all over the world, and the most important data on these diseases are presented in the papers by Bos and Perquin (1975), Thomas (1979), Epstein and Hill (1995) and Kamińska et al. (2001, 2003). Several authors reported that the severity of rose degeneration symptoms fluctuated (Bos and Perquin 1975; Thomas 1979; Epstein and Hill 1995; Kamińska et al. 2003). Most of the rose plants having severe bud proliferation symptoms, in summer recovered or showed only mild foliage malformations. However, amplification was observed in nested PCRs containing template DNA obtained from symptomatic and recovered plants, indicating low and fluctuating titre and latent phytoplasma infection (Kamińska et al. 2001, 2003).

Although rose-growth abnormalities were reported from several European countries, the climate of UK and the Netherlands seems to promote the latent infection of rose plants (Bos and Perquin 1975; Thomas 1979). A similar disease, the rose rosette, is endemic in most of the United Sta-

Abbreviations:

BAP - 6-benzylaminopurine tes (Hindal et al. 1988), which suggests a close association with environmental or climatic conditions. Epstein and Hill (1995) reported that in Iowa conditions rose rosette incidence increased more quickly in open, sunlit sides than in heavily tree-shaded areas, where many of the affected plants remained free of symptoms. The disease symptoms seem to be favoured by relatively high temperature and light intensity and tend to be masked at lower temperatures. No controlled experiments have been made on this point, however.

In 1997 Sears et al. indicated that a nonphotosynthetic leaftip culture of Oenothera contained more phytoplasmas than did those from green tissues. This suggestion was supported by Kamińska et al. (2000), who have found that reduced photosynthetic activity, connected with a reduced temperature or light intensity during storage, were responsible for the higher titre and detectability of phytoplasmas in Gladiolus shoots culture.

The knowledge about phytoplasmas has been limited by our inability to isolate them in pure culture. Micropropagation of phytoplasma-diseased plant material was first introduced by Dosba and Ducroquet (1986) and Lansac et al. (1995), to maintain the apple proliferation phytoplasma. This procedure was also applied by Cousin et al. (1990), Davies and Clark (1994) and by Bertaccini et al. (1992), to keep the collection of phytoplasma strains in several plant species. In Poland, experiments with phytoplasma mainte- 
nance and detection in tissue culture of ornamental crops were conducted by Gabryszewska et al. (2000) and Kamińska et al. (2000).

The objective of the present work was: 1) to study the presence of AY phytoplasma in micropropagated natural host of rose plants cvs Sacha and Jazz during two years at continuous temperature of $20^{\circ} \mathrm{C}$; and, 2) to examine the effect of storage conditions (medium, temperature, light and antibiotics) of in vitro shoot culture of rose cv. Sacha on appearance of disease symptoms and phytoplasma detection using PCR.

\section{MATERIAL AND METHODS}

\section{Plant material}

Plants for this study derived from apparently healthy and naturaly phytoplasma infected rose plants cultivar Sacha and Jazz collected in the greenhouse. The diseased plants had retarded growth, shoot proliferation, leaf and flower malformations and discoloration. The presence of phytoplasmas in affected, but not in the asymptomatic plants was demonstrated by polymerase chain reaction examination.

\section{Tissue culture}

Plants symptomatic and testing positive as well as asymptomatic and testing negative were used for tissue culture.

The explants, axillary buds and $5 \mathrm{~mm}$ long shoot tips of rose 'Jazz' and 'Sacha' were isolated and sterilized in $\mathrm{HgCl}_{2}(0.1 \%$ solution) for 3 minutes, and then three times washed with sterile distilled water. The shoot cultures were initiated and multiplied according to standard procedure (Podwyszyńska and Goszczyńska, 1998) on modified Murashige and Skoog (1962) medium with BAP $1.0 \mathrm{mg} \mathrm{l}^{-1}$, solidified with Agar-Agar (Sigma-Aldrich, Co., Poland). Each shoot clone derived from one initial explant was maintained separately. The shoots were cultured at temperature of $20^{\circ} \mathrm{C}$ under a $16 \mathrm{~h}$ photoperiod provided by warm, white fluorescent light (Philips TLD 36W/95; photosynthetic photo flux density - PPFD of $\left.25 \mu \mathrm{mol} \mathrm{m} \mathrm{m}^{-2} \mathrm{~s}^{-1}\right)$. The branched shoots were divided into single ones and subcultured onto the fresh medium every 4-5 weeks. Such standard culture conditions were used as a control. The micropropagated shoots of rose plants 'Jazz' and 'Sacha' were randomly tested for the presence of phytoplasma by PCR examination. The tests were performed every three months during 2 years of subculturing.

\section{Effect of medium and temperature}

Studied were: the effect of the in vitro culture conditions on the shoot development and growth parameters, as well as symptom expression and phytoplasma presence using PCR. The clone 1A of in vitro rose shoots 'Sacha', PCR positive, but symptom free, multiplied in vitro for two years were used for experiments.

In the first experiment, the shoots were maintained on medium containing BAP at concentration of 0.5 or $1 \mathrm{mg} \mathrm{l}^{-1}$ in light $\left(16 \mathrm{~h}\right.$ photoperiod, PPFD of $\left.25 \mu \mathrm{mol} \mathrm{m} \mathrm{m}^{-2} \mathrm{~s}^{-1}\right)$ or in darkness, at temperatures of $4^{\circ} \mathrm{C}$ or $20^{\circ} \mathrm{C}$ and subcultured onto a fresh medium avery 4 or 8 weeks. The observations of disease symptoms, growth parameters (fresh weight of shoots, shoot number and shoot length) and phytoplasma detection were made after the 4 or 8 weeks of subculture.
In the second experiment, the effect of temperature (15, 20 or $25^{\circ} \mathrm{C}$ ) and light intensity (PPFD -25 or $50 \mu \mathrm{mol} \mathrm{m} \mathrm{m}^{-2}$ $\mathrm{s}^{-1}$ ) on shoot development on the medium with BAP $1 \mathrm{mg}$ $1^{-1}$ were studied. The intact branched shoots, without division, were transplanted onto fresh medium after 4 weeks. Next, four weeks later, the growth parameters of shoots and phytoplasma presence were evaluated.

The effectiveness of each treatment was tested on 20 rose shoots, in four replications of 5 shoots placed in a 100 ml Erlenmeyer flask containing $25 \mathrm{ml}$ of medium. Data concerning the growth parameters were subjected to analysis of variance, and the means compared by Duncan's test at $\mathrm{P}<0.05$.

\section{Effect of antibiotics}

The clone 1A of in vitro rose shoots 'Sacha', AY-phytoplasma affected, were cultured in standard conditions described above, on BAP medium containing $1 \mathrm{mg} \mathrm{l}^{-1}$. Antibiotics, Gentamycin (gentamycin sulfate, PPH Galpharm) and Baytril (enrofloxacin, Bayer) were filter-sterilized (0.2 $\mu \mathrm{m})$ and added to the standard medium at concentration of 25 or $50 \mathrm{mg} \mathrm{l}^{-1}$, recommended by Bastiaens et al. (1983), Pollock et al. (1983), Möllers and Sarkar (1989). The shoots were multiplied on the antibiotic-containing media for two 4-week subcultures, and then they were maintained on the medium without antibiotics. The control shoots were cultured in the same conditions on standard medium without antibiotic. The shoot growth parameters as well as phytoplasma presence were evaluated after the second 4-week subculture on the antibiotic-free medium.

The effectiveness of each treatment was tested on 20 rose shoots, in four replications of 5 shoots placed in a $100 \mathrm{ml} \mathrm{Er}$ lenmeyer flask containing $25 \mathrm{ml}$ of a medium. Data concerning the growth parameters were subjected to analysis of variance, and the means compared by Duncan's test at $\mathrm{P}<0.05$.

\section{Phytoplasma detection and identification}

The micropropagated shoots of rose plants were randomly tested for the presence of phytoplasma by polymerase chain reaction (PCR) examination. In addition, leaf samples from healthy and the experimentally inoculated $\mathrm{Ca}$ tharanthus roseus L. G. Don test plants with the reference strain AY1 of aster yellows phytoplasma were also included for comparison.

\section{Polymerase chain reaction}

Total nucleic acid was extracted from fresh plant samples (1 g), according to Ahrens and Seemüller (1992).

Four pairs of primers specific to $16 \mathrm{~S}$ rDNA conserved phytoplasma region were applied in these studies - P1/P7 in direct and R16F2n/R16R2, R16(I)F1/R16(I)R1 or rA/fA in nested PCR (Lee et al. 1994, 1995; Ahrens and Seemüller 1992). The PCR amplifications were performed as previously described (Kamińska et al. 2003). PCR products were subjected to electrophoresis through $1 \%$ agarose gel followed by staining in ethidium bromide. DNA bands were visualized using UV transilluminator.

\section{Restriction enzyme analyses}

PCR products $(\sim 10 \mu \mathrm{l})$ were digested with AluI, HhaI, $H p a I I$ MseI, and RsaI endonucleases (Gibco) according to the manufacturer procedure. The restriction products were separated by electrophoresis through $6 \%$ polyacrylamide 
gel, stained with ethidium bromide and then visualized under UV light.

\section{RESULTS AND DISCUSSION}

\section{Phytoplasma detection \\ in rose plants propagated in vitro for two years}

Tissue culture: The results presented in this paper confirm the results of some earlier authors working on different plant species that it is possible to maintain aster yellows phytoplasma in the micropropagated rose plants in standard conditions for two years. The affected plants did not develop disease symptoms. However, PCR examination indicated that all shoots originated from rose plants scored diseased as well as apparently healthy were latently affected and phytoplasma detection rate increased. In the first year of the experiment phytoplasma was detectable in rose shoots sporadically while in plants stored 12-24 months this pathogen was detected in all tested plants.

The high proliferation rate and relatively strong growth was observed on rose 'Sacha'. Plantlets of rose 'Jazz' maintained on the same medium and in the same conditions showed reduced vigor, leave chlorosis and shoot tip necrosis, probably associated with high plant susceptibility to ethylene. Owing to this plant reaction rose cv. Jazz were eliminated from further experimentation.

Phytoplasma detection and identification: Using universal primers $\mathrm{P} 1 / \mathrm{P} 7$, a specific product of the expected length $\sim 1.8 \mathrm{~kb}$ was detected only in the tissues derived from the periwinkle plants inoculated with the reference strain AY1, but not from the other tested plants. If nested PCR with the universal primer pairs $\mathrm{R} 16 \mathrm{~F} 2 \mathrm{n} / \mathrm{R} 16 \mathrm{R} 2$ or $\mathrm{rA} / \mathrm{fA}$ were applied, fragments of the size of $\sim 1240$ or $\sim 560 \mathrm{bp}$, respecti- vely, were detected in all roses, scored diseased as well as healthy-looking ones, of cvs Jazz and Sacha maintained on the medium with BAP for more than one year, and only sporadically from rose plants maintained on the same medium for 3-9 months. Similar results were obtained after amplification with group-specific primer pair R16 (I)F1/R16(I)R1( 1100 bp).

The RFLP analysis of the nested-PCR products $(\sim 1240$ bp) with a restriction enzyme AluI, MseI, HpaII, HhaI and $R s a I$ indicated that the tested samples showed a restriction profile similar to those of the AY1 reference strain of aster yellows phytoplasma (Fig. 3).

Our results are in the agreement with the results of Davies and Clark (1994), who have found a much higher detectability of phytoplasma in Pyrus sp. under tissue culture conditions than in plants from the field. According to Jacoli (1978) and Mollers and Sarkar (1989), during the micropropagation of the diseased plants the phytoplasma degenerates or fails to be transmitted to the newly formed cells. Similar results obtained Gabryszewska et al. (2000), who indicated that shoots of AY-affected Limonium sinuatum maintained for 12 months in vitro culture showed the presence of phytoplasmas suggesting a degeneration process.

\section{Phytoplasma detection \\ in tissue culture of rose stored under various conditions}

Our experiment was undertaken to address the hypothesis that phytoplasma detection in the in vitro shoots might be promoted by the level of BAP, culture in increased temperature or reduced light intensity. The obtained results (Tables 1, 2 and Figs 1-3) demonstrate that the culture conditions strongly influenced plant growth but did not effect phytoplasma detection using PCR technique except for the subculture duration.

TABLE 1. Shoot growth of micropropagated rose 'Sacha' clone A stored on medium with BAP $\left(0.5\right.$ or 1 mg $\left.\mathrm{l}^{-1}\right)$ at temperature of 4 or $20^{\circ} \mathrm{C}$ in darkness or in the light (PPFD - $\left.25 \mu \mathrm{mol} \mathrm{m} \mathrm{m}^{-2} \mathrm{~s}^{-1}\right)$ after 8-week-subculture.

\begin{tabular}{lccc}
\hline $\begin{array}{l}\text { Culture conditions: } \\
\text { temperature, light, BAP concentration }\left(\mathrm{mg} \mathrm{l}^{-1}\right)\end{array}$ & Fresh weight of shoots $(\mathrm{mg})$ & Shoot number \\
\hline $4^{\circ} \mathrm{C}$, darkness, & $0.5 \mathrm{BAP}$ & $370.0 \mathrm{ab}$ & $2.3 \mathrm{a}$ \\
$4^{\circ} \mathrm{C}$, darkness, & $1.0 \mathrm{BAP}$ & $276.6 \mathrm{a}$ & $2.9 \mathrm{ab}$ \\
$4^{\circ} \mathrm{C}$, light, & $0.5 \mathrm{BAP}$ & dead & dead \\
$4^{\circ} \mathrm{C}$, light, & $1.0 \mathrm{BAP}$ & $213.4 \mathrm{a}$ & $1.6 \mathrm{a}$ \\
$20^{\circ} \mathrm{C}$, darkness, & $0.5 \mathrm{BAP}$ & $702.9 \mathrm{c}$ & $4.0 \mathrm{bc}$ \\
$20^{\circ} \mathrm{C}$, darkness, & $1.0 \mathrm{BAP}$ & $621.4 \mathrm{bc}$ & $3.9 \mathrm{bc}$ \\
$20^{\circ} \mathrm{C}$, light, & $0.5 \mathrm{BAP}$ & $809.9 \mathrm{c}$ & $5.0 \mathrm{~cd}$ \\
$20^{\circ} \mathrm{C}$, light, & $1.0 \mathrm{BAP}$ & $1139.4 \mathrm{~d}$ & $59.5 \mathrm{~d}$ \\
\hline
\end{tabular}

Means followed by the same letter do not differ at $5 \%$ level of significance according to Duncan's multiple range t-test $(\mathrm{P}<0.05)$. Means separation for each parameter.

TABLE 2. Shoot growth of micropropagated rose 'Sacha' clone A kept on medium with BAP $\left(1 \mathrm{mg} \mathrm{l}^{-1}\right)$ at different temperature $\left(15,20\right.$ or $\left.25^{\circ} \mathrm{C}\right)$ and light intensity (PPFD 25 or $50 \mu \mathrm{mol} \mathrm{m} \mathrm{m}^{-2} \mathrm{~s}^{-1}$ ) after the second 4-week-subculture.

\begin{tabular}{lcc}
\hline $\begin{array}{l}\text { Culture conditions: } \\
\text { temperature, PPFD }\left(\mu \mathrm{mol} \mathrm{m}{ }^{-2} \mathrm{~s}^{-1}\right)\end{array}$ & Fresh weight of shoots $(\mathrm{mg})$ & Shoot number \\
\hline $15^{\circ} \mathrm{C}$, PPFD 25 & $242.4 \mathrm{a}$ & $4.0 \mathrm{ab}$ \\
$15^{\circ} \mathrm{C}$, PPFD 50 & $227.9 \mathrm{a}$ & $4.0 \mathrm{ab}$ \\
$20^{\circ} \mathrm{C}$, PPFD 25 & $440.7 \mathrm{~b}$ & $4.2 \mathrm{ab}$ \\
$20^{\circ} \mathrm{C}$, PPFD 50 & $361.8 \mathrm{ab}$ & $4.8 \mathrm{~b}$ \\
$25^{\circ} \mathrm{C}$, PPFD 25 & $250.0 \mathrm{a}$ & $3.2 \mathrm{a}$ \\
$25^{\circ} \mathrm{C}$, PPFD 50 & $251.7 \mathrm{a}$ & $3.8 \mathrm{a}$
\end{tabular}

Explanations as in Table 1. 


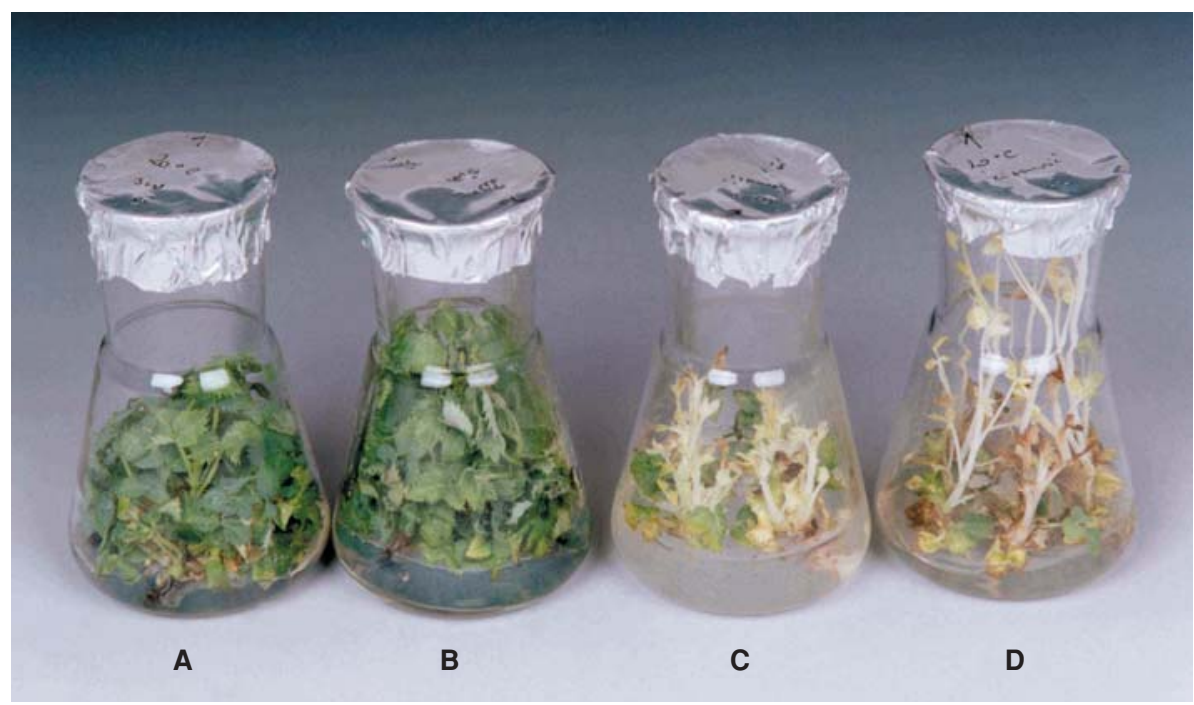

Fig. 1. Rose shoots 'Sacha' clone A phytoplasma-affected micropropagated on the medium with BAP 0.5 (A and C) or $1 \mathrm{mg} \mathrm{l}^{-1}$ (B and D) at $20^{\circ} \mathrm{C}$ in light $(\mathrm{A}, \mathrm{B})$ or in darkness $(\mathrm{C}, \mathrm{D})$.
A

$\begin{array}{llllllllll}M & 1 & 2 & 3 & 4 & 5 & 6 & 7 & \text { AY1 } & \text { H }\end{array}$

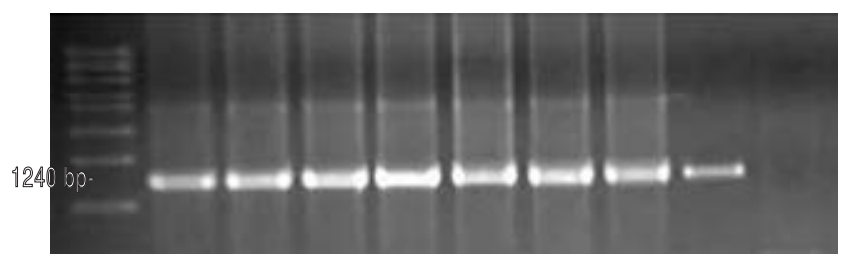

B

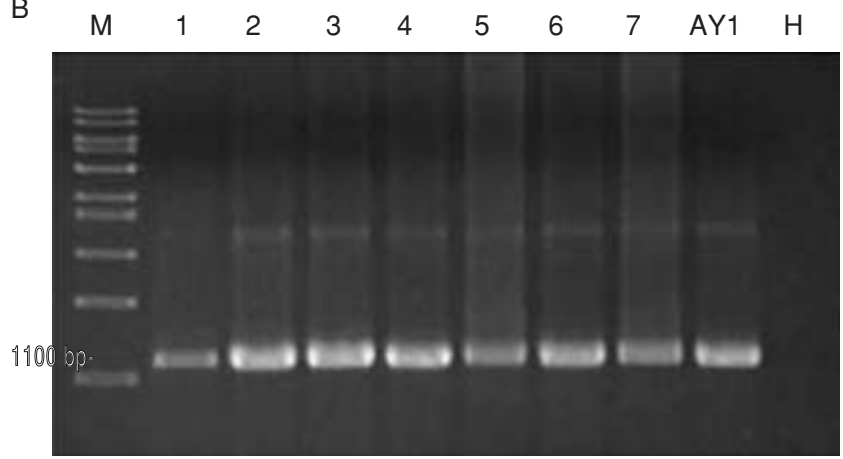

Fig. 2. Electrophoresis of nested PCR products obtained after amplification of $16 \mathrm{~S}$ rDNA phytoplasma fragments form micropropagated rose 'Sacha' clone A shoots (lines 1-7) kept for four weeks on the medium with $\mathrm{BAP}$ at $4^{\circ}(1,2), 15^{\circ}(3,4), 20^{\circ}(5,6)$ or $25^{\circ} \mathrm{C}(7)$ in darkness $(1,3$, $6)$ or in light $(2,4,5,7)$. AY1 - aster yellows phytoplasma reference strain; $\mathrm{H}$ - healthy periwinkle plant; $\mathrm{M}$ - molecular marker - $1 \mathrm{~kb}$ DNA ladder (Sigma-Aldrich).

Nested PCR was performed using P1/P7 followed by amplification with the primer pairs: A) R16F2n/R16R2, B) R16 (I)F1/R16 (I)R1.

Effect of medium and temperature: Micropropagated rose shoots 'Sacha' that developed from AY phytoplasma affected plants maintained in the conditions of decreased BAP level and at different temperature did not develop disease symptoms. However, the obtained results demonstrate that the storage conditions strongly influenced plant growth. In standard (control) conditions (temperature of $20^{\circ} \mathrm{C}, \mathrm{PPFD}$ at $25 \mu \mathrm{mol} \mathrm{m} \mathrm{m}^{-2} \mathrm{~s}^{-1}$ and BAP concentration of 1 $\mathrm{mg}^{-1}$ ), the rose shoots were robust, dark green, with the highest fresh weight and shoot number (Table 1, Fig. 1A, B). The shoots kept in the same conditions on the medium with lower BAP concentration had a lower fresh weight. The shoots stored on medium with BAP 1 or $0.5 \mathrm{mg} \mathrm{l}^{-1}$, at $4^{\circ} \mathrm{C}$ in darkness, were dark green and their growth was inhibited. In rose shoots maintained on medium containing

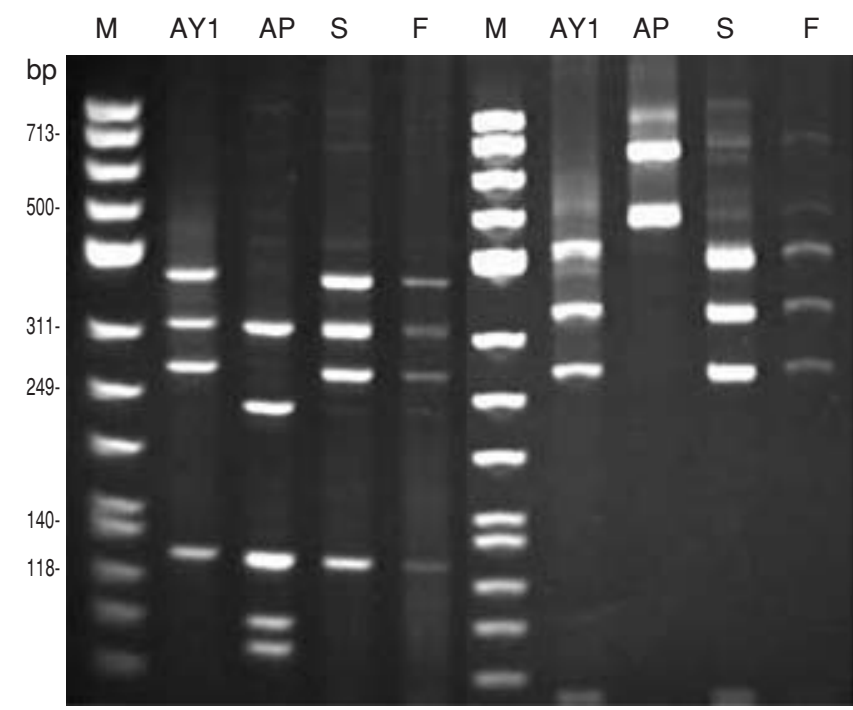

Fig. 3. Restriction profiles after MseI and RsaI digestion of the nested PCR products obtained using DNA isolated from micropropagated rose 'Sacha' (S) kept four weeks at $20^{\circ} \mathrm{C}$ on medium with BAP $1 \mathrm{mg} \mathrm{l}^{-1}$ in the light and from rose 'Frisco' (F) growing in the greenhouse; phytoplasma reference strains: apple proliferation (AP), aster yellows (AY1). M - molecular weight marker 174DNA/HinfI (Promega).

BAP at lower concentration, at $4^{\circ} \mathrm{C}$ in the presence of light, the partial leaf necrosis was observed at the end of 4-week storage and all shoots died when stored for 8 weeks. The shoots cultured at $20^{\circ} \mathrm{C}$ in darkness were thin and etiolated (Fig. 1C, D).

When the shoots were cultured on medium with BAP 1 $\mathrm{mg}^{-1}$ at reduced $\left(15^{\circ} \mathrm{C}\right)$ or increased temperature $\left(25^{\circ} \mathrm{C}\right)$ and increased light intensity $\left(50 \mu \mathrm{mol} \mathrm{m} \mathrm{m}^{-2} \mathrm{~s}^{-1}\right)$, their growth was retarded (Table 2). In such conditions, the shoots were chlorotic; their fresh weight as well as length were lower than those of plants maintained at temperature of $20^{\circ} \mathrm{C}$ and PPFD 25-50 $\mu \mathrm{mol} \mathrm{m} \mathrm{m}^{-2} \mathrm{~s}^{-1}$.

After the amplification with the universal primer pair P1/P7 (direct PCR) no evidence was obtained for the presence of phytoplasmas from the tested plants kept under different conditions. However, if nested PCR with the universal - R16F2n/R16R2 (Fig. 2A) and fA/rA or group 16SrI specific - R16(I)F1/R1 (Figs 2B, 3) primer pairs were applied, the specific bands were detected from the micropropagated roses, which were tested after 4 weeks of 
TABLE 3. Effect of antibiotics added to the multiplication media on the shoot growth of rose 'Sacha' clone A cultured in vitro.

\begin{tabular}{lcc}
\hline Antibiotics $\mathrm{mg} \mathrm{l}^{-1}$ & $\begin{array}{c}\text { Fresh weight } \\
\text { of shoots }(\mathrm{mg})\end{array}$ & Shoot number \\
\hline Control, untreated & $341.7 \mathrm{c}$ & $4.4 \mathrm{~d}$ \\
Baytril 25.0 & $192.1 \mathrm{a}$ & $2.3 \mathrm{~b}$ \\
Baytril 50.0 & $210.7 \mathrm{ab}$ & $2.3 \mathrm{~b}$ \\
Gentamicin 25.0 & $196.6 \mathrm{a}$ & $2.1 \mathrm{~b}$ \\
Gentamicin 50.0 & $150.3 \mathrm{a}$ & $0.9 \mathrm{a}$ \\
\hline
\end{tabular}

Explanations as in Table 1.

maintaince in tissue culture (as well as from the periwinkle experimentally infected with the phytoplasma reference strain, AY1), but not from the plants maintained for 8 weeks without transplanting. PCR analysis indicated that plants stored for 4 weeks on the medium with BAP $1 \mathrm{mg} \mathrm{l}^{-1}$ at $4,15,20$ or $25^{\circ} \mathrm{C}$ have the same level of detectable phytoplasmas. The detectability of phytoplasma in infected plants stored on medium with reduced level of BAP, in light or in darkness was not effected. However, in plants micropropagated and stored on the medium with BAP 0.5 or $1.0 \mathrm{mg} \mathrm{l}^{-1}$ at 4 or $20^{\circ} \mathrm{C}$ for 8 weeks without transplanting, we failed to detect phytoplasmas. Another four weeks later, after transplanting, phytoplasmas were detected.

The obtained results indicated that the application of reduced level of BAP in the medium did not influence the detectability of phytoplasma in the micropropagated rose 'Sacha' shoots. The involvement of growth regulators in pathogenesis of phytoplasma disease has been reported by Chen et al. (1991). It is thought that the symptoms of phytoplasma disease are mainly caused by the rise of the cytokinin/auxin ratio in infected plants. Dai et al. (1997) have stated that the elimination of phytoplasma from the infected Morus alba culture may be related to the decrease of the cytokinin/auxin ratio. Cytokinin plays an important role in the distribution of nutrient materials (Bidwell 1979). The decrease of cytokinins can limit the nutrients required by the phytoplasmas and inhibit their reproduction; the resumption of normal growth of the stem segments can raise their resistance to the phytoplasma (Dai et al. 1997).

In our experiments phytoplasma was detectable in actively growing shoots subcultured every four weeks, but not in plants maintained on the same medium without transplanting, suggesting degeneration of phytoplasmas in older tissues. Petru et al. (1971) observed phytoplasma transmission only in fast growing tissues showing prompt organogenesis, but not in cultures with retarded organogenesis. It seems likely that regular transplanting stimulates tissue growth and phytoplasma detection in rose cultures.

The obtained results did not support the earlier report which suggests that the reduced photosynthetic activity connected with the reduced temperature or light intensity during storage were responsible for the higher titre and detectability of phytoplasmas in Gladiolus shoots culture (Kamińska et al. 2000). In this aspect our results are also in disagreement with the results of Sears et al. (1997) who stated that nonphotosynthetic leaftip culture of Oenothera contained more phytoplasmas than did those from green tissues. On the other hand, we failed to support the suggestion of Epstein and Hill (1995), who observed that higher temperature and light intensity promoted development of rose rosette disease.
Effect of antibiotics: As is shown in Table 3, the antibiotics used in our culture media were phytotoxic for the micropropagated rose shoots. The roses grown on antibiotic containing medium manifested stunted growth and severe leaf and shoot chlorosis. The most severe inhibitory effect was observed for Gentamycin-treated plants at concentrations of 25 or $50 \mathrm{mg} \mathrm{l}^{-1}$. It was observed that, respectively, $6.3 \%$ and $12.5 \%$ of shoots died during the second subculture on the Gentamycin-containing medium (data not presented). After the shoot transplanting onto the medium without antibiotics, chlorosis ceased and the shoots renewed normal growth.

In spite of this phytotoxic effect, the applied concentration of Gentamycin and Baytril was so low that no direct effect on the phytoplasma was evidenced. The phytoplasma present in Sacha cultivar was detected by nested PCR 8 weeks after culturing in antibiotic-containing as well as antibiotic-free media.

Further research work may be useful to study the conditions promoting phytoplasma titre and detection in diseased rose plants.

\section{ACKNOWLEDGMENT}

This study was partially supported by the State Committee for Scientific Research (KBN), Grant No. 6P 06A 00421.

\section{LITERATURE CITED}

AHRENS U., SEEMÜLLER E. 1992. Detection of DNA of plant pathogenic mycoplasma like organisms by a polymerase chain reaction that amplifies a sequence of the 16Sr RNA gene. Phytopathology 82: 828-832.

BASTIAENS L., MAENE L., HARBAOUI Y., VAN SUMERE C., VANDE CASTEELE K.L., DEBERGH P.C. 1983. The influence of antibacterial products on plant tissue cultures. Med. Fac. Landbouww. Rijsuniv. Gent. 48: 13-24.

BERTACCINI A., DAVIS R.E., LEE I.-M. 1992. In vitro micropropagation for maintenance of mycoplasma-like organisms in infected plant tissue. Hort Sci. 27: 1041-1043.

BIDWELL R.G.S. 1979. Action of hormones and growth substances. In: Bidwell R.G.S., (ed.), Plant Physiology. New York: Macmillan, 573.

BOS L., PERQUIN F.W. 1975. Rose bud proliferation, a disorder of still unknown etiology. Neth. J. Plant Pathol. 81: 187-198.

COUSIN M.T., ROUX J., MILLET N., MICHEL M.F. 1990. Maintenance of MLOs (mycoplasma-like organisms) on Populus alba micropropagation. J. Phytopathol. 130: 17-23.

CHEN Z.W., CHEN Y.X., CHEN T.A. 1991. Advance in the study of Jujube witches' broom disease. Journal of Nanjing Agricultural University, 14: 49-55.

DAI Q., HE F.T., LIU P.Y. 1997. Elimination of phytoplasma by stem culture from mulberry plants (Morus alba) with dwarf disease. Plant Pathol. 46: 56-61

DAVIES D.L., CLARK M.F. 1994. Maintenance of mycoplasmalike organisms occurring in Pyrus species by micropropagation and their elimination by tetracycline therapy. Plant Pathol. 43: 819-823.

DOSBA F., DUCROQUET J.P. 1986. Experiments with apple proliferation and detection using in vitro culture. Acta Hort. 193: 323-328.

EPSTEIN A.H., HILL J.H. 1995. The biology of rose rosette disease: a mite-associated disease of uncertain aetiology. J. Phytopathol. 143: 353-360. 
GABRYSZEWSKA E., KAMIŃSKA M., KORBIN M., RUDZIŃSKA-LANGWALD A. 2000. Micropropagation of phytoplasma-affected Limonium. Acta Soc. Bot. Pol. 69: 109-113.

HINDAL D.F., AMRINE J.W., WILLIAMS R.L., STASNY T.A. 1988. Rose rosette disease on multiflora rose (Rosa multiflora) in Indiana and Kentucky. Weed Technol. 2: 442-444.

JACOLI G.G. 1978. Sequential degeneration of mycoplasma like bodies in plant tissue cultures infected with aster yellows. Can. J. Bot. 56: 133-140.

KAMIŃSKA M., GABRYSZEWSKA E., KORBIN M. 2000. Phytoplasma detection in tissue culture of Gladiolus plants grown under various conditions. Acta Soc. Bot. Pol. 69: 197-200 .

KAMIŃSKA M., DZIEKANOWSKA D., RUDZIŃSKA-LANGWALD A. 2001 Detection of phytoplasma infection in rose, with degeneration symptoms. J. Phytopathol. 149: 3-10.

KAMIŃSKA M., ŚLIWA H., MALINOWSKI T., SKRZYPCZAK C. 2003. The association of aster yellows phytoplasma with rose dieback disease in Poland. J. Phytopathol. 151: 69-476.

LANSAC M., JARAUSCH W., DOSBA F. 1995. Maintenance of two types of apple proliferation phytoplasmas in the micropropagated non-natural host Pyronia veitchii. Adv. Hort. Sci. 9: 140-143.

LEE I.-M., GUNDERSEN D.E., HAMMOND R.W., DAVIS R.E. 1994. Use of mycoplasmalike organism (MLO) groupspecific oligonucleotide primers for nested-PCR assays to de- tect mixed-MLO infections in a single host plant. Phytopathology 84: 559-566.

LEE I.-M., BERTACCINI A., VIBIO M., GUNDERSEN D.E. 1995. Detection of multiple phytoplasmas in perennial fruit trees with decline symptoms in Italy. Phytopathology 85: 728-735.

MURASHIGE T., SKOOG F. 1962. A revised medium for rapid growth and bioassays with tobacco culture. Physiol. Plant. 15: 473-497.

MÖLLERS C., SARKAR S. 1989. Regeneration of healthy plants from Catharanthus roseus infected with mycoplasma-like organisms through callus culture. Plant Science 60: 83-89.

PETRU E., LIMBERT M., ULRYCHOVA M., BRCAK J. 1971. Growth and infectivity of callus cultures of tomato plants infected with a mycoplasma disease - potato witches' broom. Biol. Plant. 17: 352-356.

PODWYSZYŃSKA M., GOSZCZYŃSKA D.M. 1998. Effect of inhibitors of ethylene biosynthesis and leaf senescence in vitro. Acta Physiol. Plant. 20: 91-98.

POLLOCK K., BARFIELD D.G., SHIELDS R. 1983. The toxicity of antibiotics to plant cell cultures. Plant Cell Rep. 2: 36-39.

SEARS B.B., KLOMPARENS K.L., WOOD J.I., SCHEWE G. 1997. Effect of altered levels of oxygen and carbon dioxide on phytoplasma abundance in Oenothera leaftip cultures. Physiological and Molecular Plant Pathology 50: 275-287.

THOMAS B.J. 1979. Some degeneration and dieback diseases of the rose. Ann. Rep. Glasshouse Crops Res Inst. 1979, 178-190. 